\title{
Effects of Grazing on Soil Parameters in Meadow Ecosystems
}

\section{Çayır Ekosistemlerinde Otlatmanın Toprak Parametrelerine Etkileri}

\section{Research Article}

\section{Erkan Yalçın' ${ }^{*}$, Ahmet Doğan', Adnan Akçin²}

'Ondokuz Mayıs University, Sciences-Arts Faculty, Biology Department, Samsun, Turkey.

${ }^{2}$ Amasya University, Sciences-Arts Faculty, Biology Department, Amasya, Turkey.

\section{A B S T R ACT}

$\mathrm{T}$

his study was carried out to determine the effects of grazing on soil parameters in the meadow ecosystems in the alluvial delta plain of Samsun-Turkey. Five $5 \times 5 \mathrm{~m}$ exclosures were established in the homogeneous stands in terms of habitat conditions and floristic composition in the study area during 2000-2003. The top of soil was firstly removed and then soil samples were taken from inside and outside of exclosures at a depth of $20 \mathrm{~cm}$ in each month for a year. Soil organic matter, $\mathrm{pH}$, nitrogen, phosphorus, potassium, $\mathrm{CaCO}_{3}$ and total salinity were measured by standard methods. In general, $\mathrm{CaCO}_{3}$ and total salinity exhibited statistically significant differences between the grazed and ungrazed parts.

\section{Key Words}

Ecosystem, meadow, soil, Samsun.

\section{ÖZET}

u çalışma Samsun-Türkiye'de alüvyal delta ovalarındaki çayır ekosistemlerinde otlatmanın toprak parametrelerine etkilerini belirlemek için yürütülmüştür. 2000-2003 yıllarında $5 \times 5$ m lik beş adet eksklosür çalışma alanında floristik bileşim ve habitat koşulları bakımından homojen alanlarda kurulmuştur. Toprak örnekleri eksklosürlerin içerisinden ve dışından olmak üzere en üst toprak yüzeyi uzaklaştırıldıktan sonra 20 $\mathrm{cm}$ derinlikten bir yıl boyunca aylık olarak alınmıştır. Toprak organik maddesi, pH, azot, fosfor, potasyum, $\mathrm{CaCO}_{3}$ ve toplam tuzluluk standart yöntemlerle ölçülmüştür. Genellikle $\mathrm{CaCO}_{3}$ ve toplam tuzluluk otlatılan ve korunan kısımlar arasında istatistiksel olarak önemli derecede farklı çıkmıştır.

\section{Anahtar Kelimeler}

Ekosistem, çayır, toprak, Samsun.

Article History: Received: Jun 22, 2015; Revised: Feb 12, 2016; Accepted: Mar 20, 2016; Available Online: Apr 1, 2016.

DOI: 10.15671/HJBC.20164418124

Correspondence to: E. Yalçın; Ondokuz Mayıs University, Sciences-Arts Faculty Biology Department, Samsun, Turkey. 


\section{INTRODUCTION}

razing is known to be an important biotic $\checkmark$ factor affecting the biomass and soil characteristics with the studies on meadow ecosystems in the worldwide [1-3]. Johnston et al. (1971) [4] reported that the long-term intensive grazing with cattle converted the soil $\mathrm{pH}$ from 5.7 to 6.2 , the color of Ah horizon from black to dark brown, and reduced the soil organic matter moisture and total phosphorus while increased available phosphorus and soil temperature in Festuca sp. meadow ecosystems. The results of soil analysis indicated to decrease in $\mathrm{pH}$ and moisture in the heavy grazing meadow [5].

The climate, landform, soil and living organisms have continuously influenced the meadow ecosystems. Meadow vegetation and grazing livestocks constitute the complex components of an ecosystem. Therefore, it should be investigated not only the flora and vegetation of the meadow, but also the effects of grazing on the soils.

Although there have been many studies to investigate the grazing impact on the ecosystem's basic functions such as primary productivity, floristic composition and soil properties in the worldwide, there is almost no work on this sense in our country. We conducted this study in order to demonstrate the impact of grazing on the soil parameters in the lowland meadow ecosystems in the Middle Black Sea Region.

\section{MATERIALS AND METHODS}

\section{Study Area}

The study area is situated on the coastline of the Central Black Sea Region in the north of Turkey (Figure 1). The natural alluvial grasslands are exist in the Central Black Sea Region adjacent to Kızılırmak and Yeşilırmak rivers, respectively. These large areas have been grazed and mowned since 1900's traditionally, but there hasn't been any management or conservation study in the area. This area floristically belongs to the Euxine province of the Euro-Siberian phytogeographical region. The studied grasslands are used as rangeland. The mean annual temperatures in the Kızılırmak and Yeşilırmak deltas are $13.66^{\circ} \mathrm{C}$ and $14.30^{\circ} \mathrm{C}$ respectively. The annual rainfall is 672.41 and $922.10 \mathrm{~mm}$ in the Kızılırmak and Yeşilırmak deltas respectively.

The study area consists of alluvial sediment soils carried by the Kızılırmak and Yeşilırmak rivers. Soil is typically dark grayish brown (Vertisol) and soil depth is meanly $1 \mathrm{~m}$ [6]. On average, soil texture is $48 \%$ clay, $33 \%$ silt and $19 \%$ sand.

The natural vegetation on the area is distributed by temperate grasslands of which consisted by three plant associations [7]. The vegetation in the study area is strongly affected by long-term and over-grazing. Grasslands in the western part of the study area are composed of herbaceous perennial mesophytic and xerophytic species, such as Hordeum geniculatum All. Polypogon monspeliensis (L.) Desf., Centaurium pulchellum (Sw.) Druce and Romulea ramiflora Ten. subsp. ramiflora, Cynodon dactylon (L.) Pers. var. dactylon, Lotus corniculatus L. var. tenuifolius L., Bellis perennis L., Plantago lanceolata L:, Lolium perenne L., Trifolium physodes M.Bieb. var. physodes and Medicago disciformis DC. In the eastern part of the study area, grasland vegetation is composed of more herbaceous perennial mesophytic species, such as Paspalum distichum L., Ranunculus ophioglossifolius Vill., Trifolium repens L. var. repens, Lolium perenne, Cynodon dactylon var. dactylon, Plantago lanceolata, Potentilla reptans L. and Rumex acetosella $\mathrm{L}$.

\section{Soil Sampling, Analysis and Data Processing}

Five localities were selected to obtaine the soil samples. One floristically homogeneous permanent plot of $(5 \times 5 \mathrm{~m})$ was selected and fenced in each stand in 2000 to take soil samples. So, totaly five exclosures established to protect from grazing on studied meadows. The grazing sites have been continuously uncontrolled grazed for at least 20 years before building the exclosures by the horses, cows, sheeps and goats, and were not burned the last 15 years.

Since nutrients are concentrated mainly on the topsoil [8], we sampled only the upper $20 \mathrm{~cm}$ of the A1 horizon. Throughout a year, soil samples 


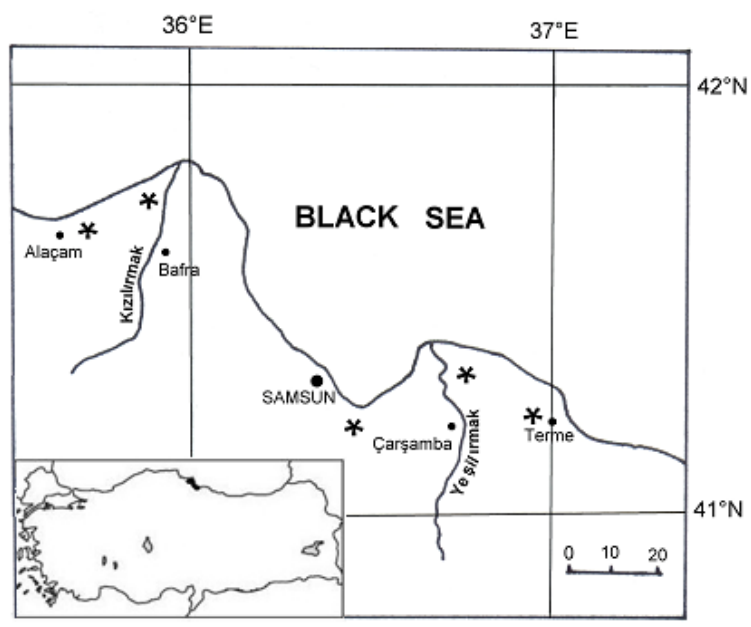

Figure 1. Map of the study area. * Selected stands.

(four samples per month) were taken both inside and outside of exclosures at each locality. The soil samples were air dried for 48-72 $\mathrm{h}$ and sieved through a $2 \mathrm{~mm}$ sieve before the chemical analyses $[9,10]$.

Electrical conductivity (dS. $\left.\mathrm{m}^{-1}\right)$ was determined in soil-water extracts at 1:1 (w:v) using a Jenway analyser and converted to the percentage of the total salinity. $\mathrm{pH}$ values were measured in deionized water (1/1). Soil nitrogen (\%) was determined by micro Kjeldahl method. Soil phosphorus (\%) was determined spectrophotometrically following the extraction by ammonium acetate. Soil potassium (\%) was determined by using a Petracourt PFP-7 flame photometer after nitric acid wet digestion. $\mathrm{CaCO}_{3}$ (\%) concentrations were determined by using a Scheibler calcimeter [9].

Descriptive statistical analyses were performed by using SPSS 21.0 version [11]. The data obtained from grazing and ungrazing parts were evaluated with one-way analysis of variance (ANOVA) and Pearson's correlation test.

\section{RESULTS}

Grazing livestock units (BBHB) and area (ha) of the different localities were showed in Table 1 by using data of Samsun Provincial Directorate of Agriculture. According to Table 1, there were heavy grazing intensity in Tekkeköy, Çarşamba,
Terme and Bafra respectively, but there was no statistical data about Alaçam. However, the number of grazing animals such as geese and wild horses have also been observed during our field work in the studied stands. Furthermore, after October, the migration of sheep breeders was observed from high plateau to lowland meadows to spend the winter with many sheep in Bafra. So, we think that the grazing pressure can be higher than the calculations made on the basis of official data.

In general, there were statistically significant differences in terms of $\mathrm{CaCO}_{3}$ and total salinity between grazing and ungrazing soils (Table 2). When the data were annualy evaluated, soil salinity and $\mathrm{CaCO}_{3}$ contents were higher in grazing than ungrazing meadow ecosystems in the study area (Figure 2). Conversely, soil pH was high at grazing lands, amounts of soil organic matter were high at ungrazed stands (Figure 3). When we seasonally investigated the effects of grazing, soil $\mathrm{CaCO}_{3}$ for all seasons while soil total salinity at winter and summer significantly changed (Table 3) and both of them were higher in grazing parts (Figure 4).

Beside, the nitrogen content of the soil in the spring, the phosphorus content also showed significant differences in fall depend on grazing (Table 3). Soil nitrogen and phosphorus contents were generally higher in ungrazed stands than grazed (Figure 5). 


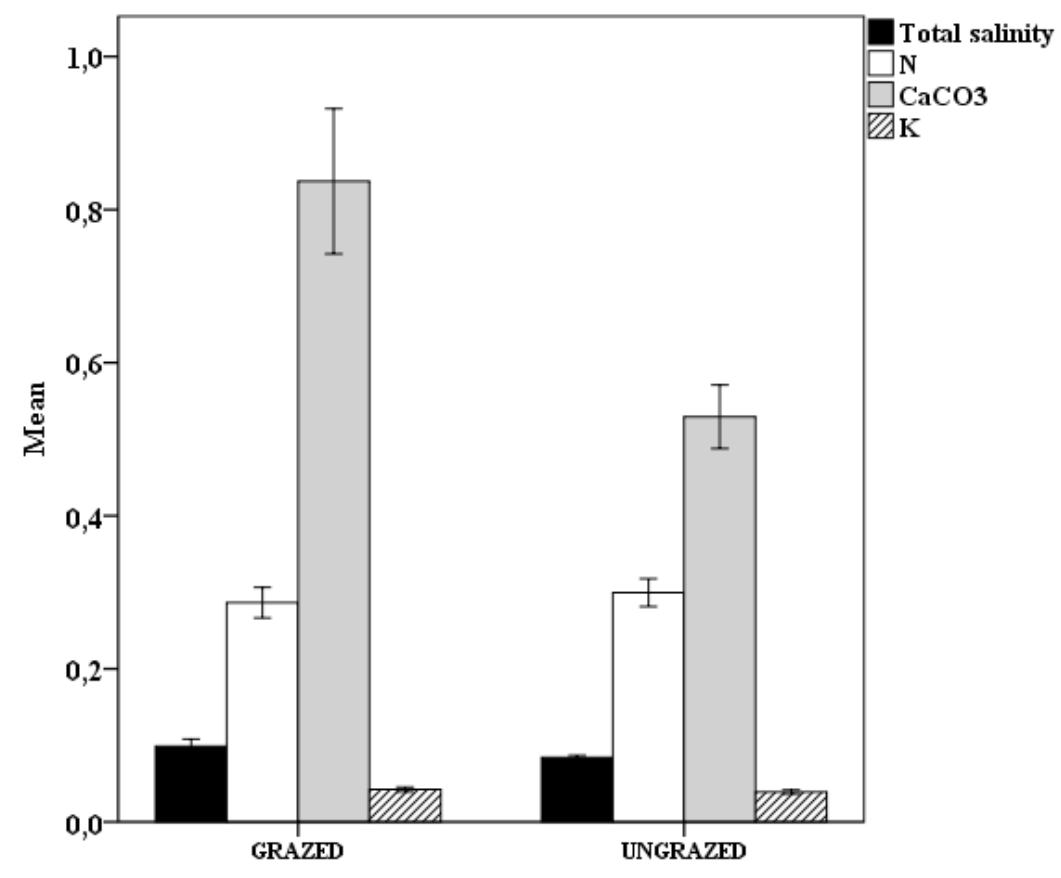

Figure 2. The annual average values of the total soil salinity, nitrogen, calcium carbonate and potassium between grazed and ungrazed stands of the study area $(n=48)$.

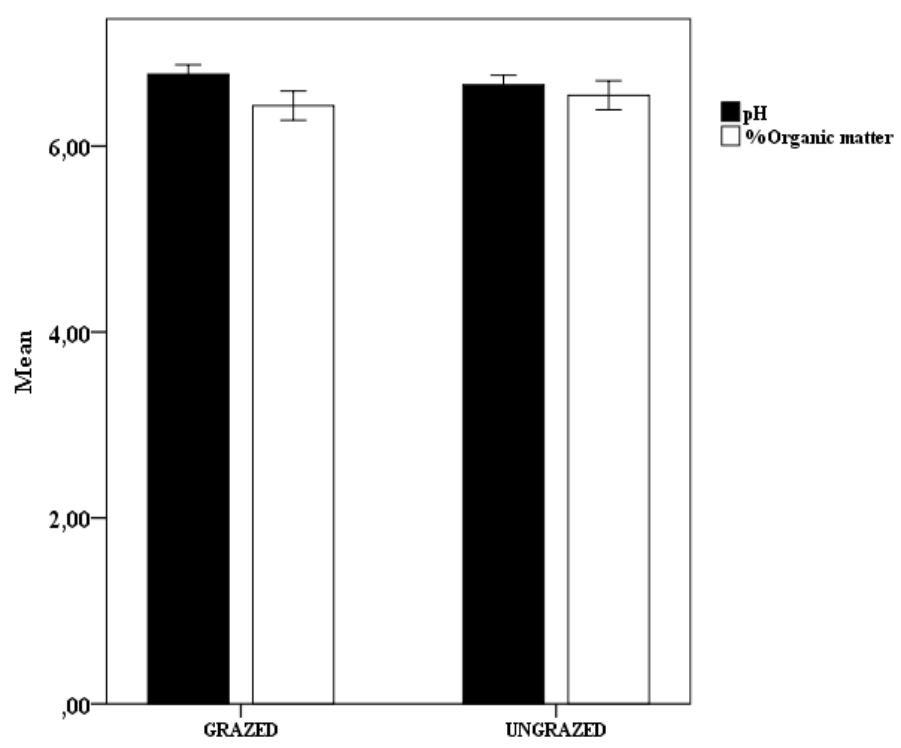

Figure 3. The annual average values of the soil $\mathrm{pH}$ and organic matter between grazed and ungrazed stands of the study area $(n=48)$. 


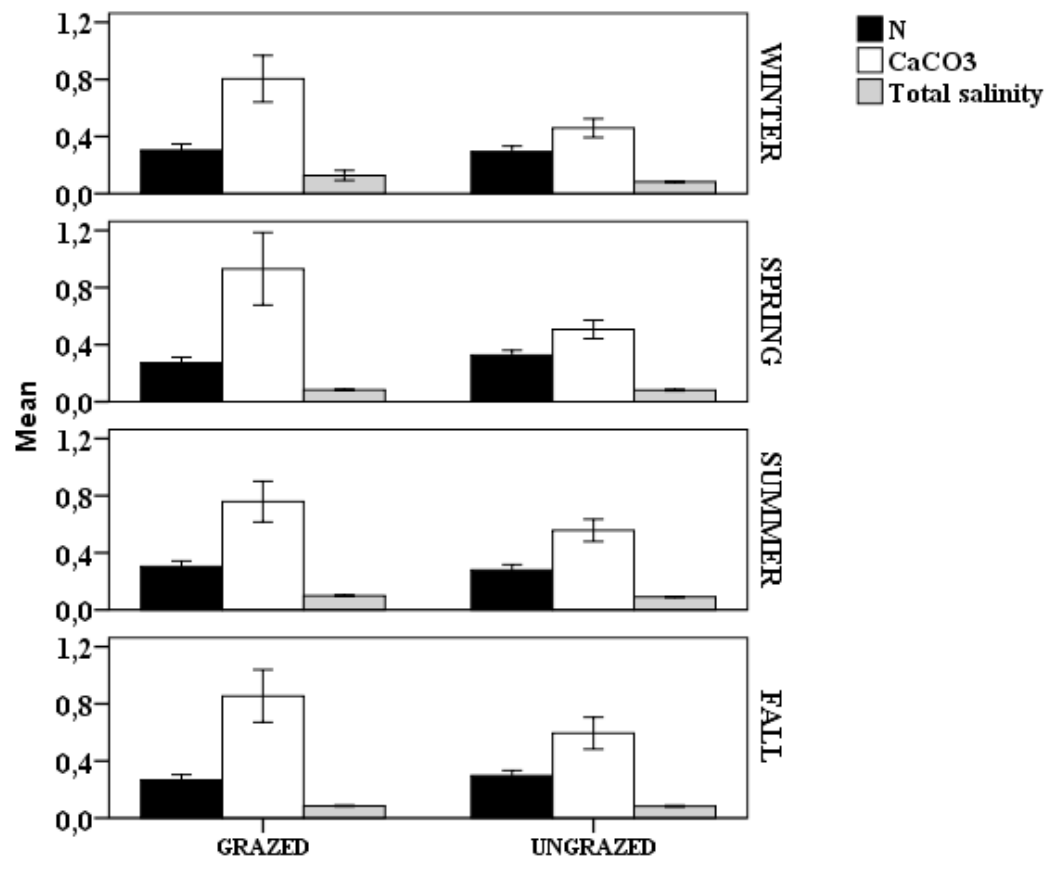

Figure 4. The seasonal average values of the total soil salinity, nitrogen, calcium carbonate and potassium between grazed and ungrazed stands of the study area $(n=12)$.

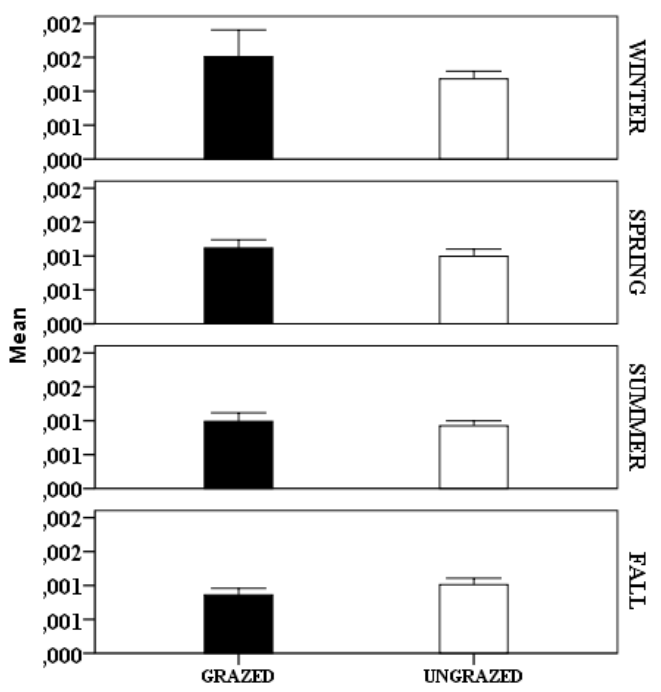

Figure 5. The seasonal average values of the total soil phosphorus between grazed and ungrazed stands of the study area $(n=12)$. 
166 | E. Yalçın et al. / Hacettepe J. Biol. \& Chem., 2016, 44 (2), 161-171

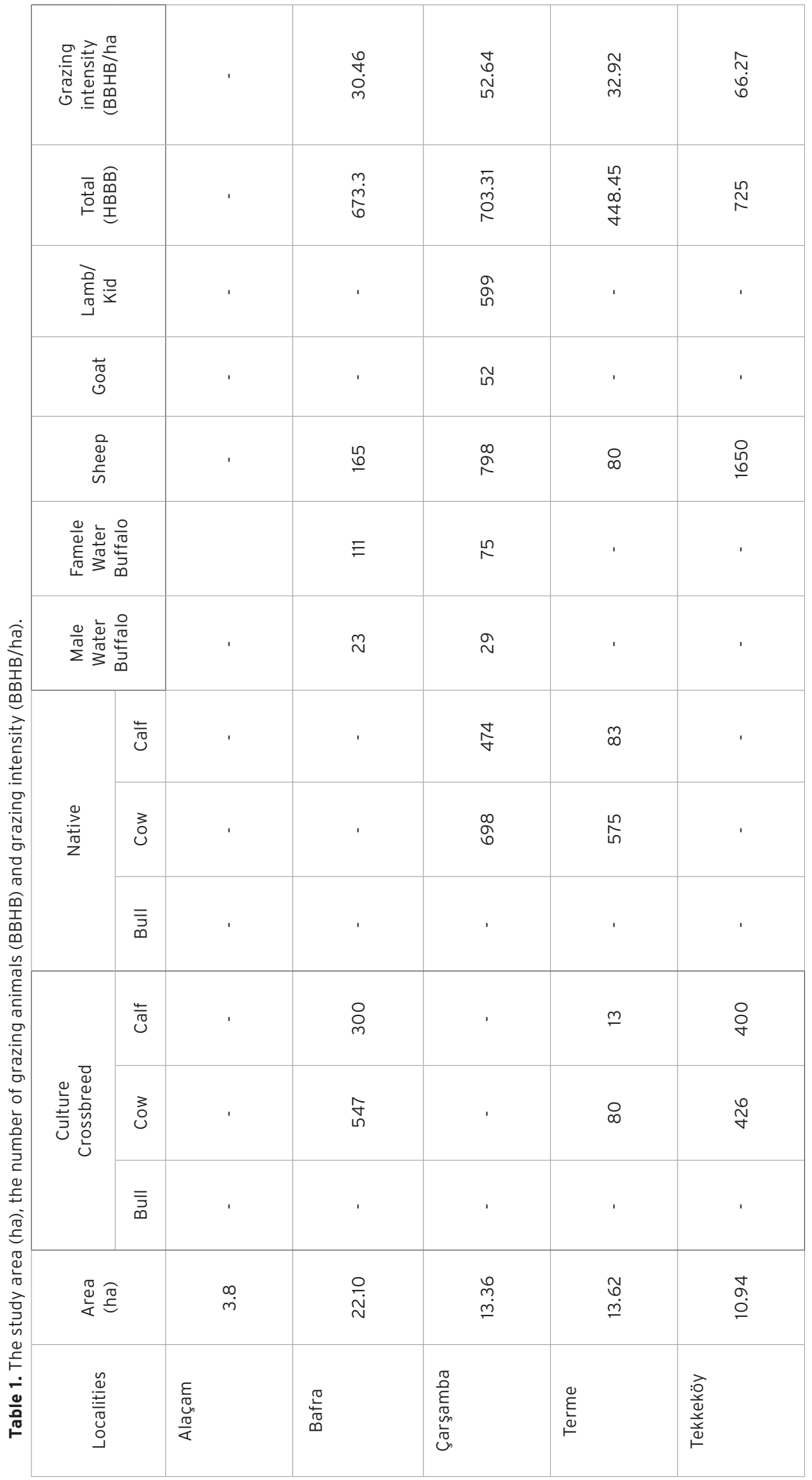


Table 2. Annual comparison of soil parameters by using one-way variance analysis (ANOVA) between grazing and ungrazing parts.

\begin{tabular}{|c|c|c|c|c|c|c|}
\hline $\begin{array}{c}\text { Solid } \\
\text { Parameters }\end{array}$ & & & $\mathrm{df}$ & Mean Square & $\mathrm{F}$ & Sig. \\
\hline \multirow{3}{*}{$\mathrm{N}$} & $\begin{array}{c}\text { Between } \\
\text { Groups }\end{array}$ & 0.01 & 1 & 0.01 & 0.93 & 0.33 \\
\hline & $\begin{array}{l}\text { Within } \\
\text { Groups }\end{array}$ & 6.66 & 382 & 0.01 & & \\
\hline & Total & 6.68 & 383 & & & \\
\hline \multirow{3}{*}{$\mathrm{P}$} & $\begin{array}{l}\text { Between } \\
\text { Groups }\end{array}$ & 0.01 & 1 & 0.01 & 2.03 & 0.15 \\
\hline & $\begin{array}{l}\text { Within } \\
\text { Groups }\end{array}$ & 0.01 & 382 & 0.01 & & \\
\hline & Total & 0.01 & 383 & & & \\
\hline \multirow{3}{*}{ K } & $\begin{array}{l}\text { Between } \\
\text { Groups }\end{array}$ & 0.01 & 1 & 0.01 & 2.52 & 0.11 \\
\hline & $\begin{array}{l}\text { Within } \\
\text { Groups }\end{array}$ & 0.15 & 382 & 0.01 & & \\
\hline & Total & 0.15 & 383 & & & \\
\hline \multirow{3}{*}{$\mathrm{CaCO}_{3}$} & $\begin{array}{c}\text { Between } \\
\text { Groups }\end{array}$ & 9.08 & 1 & 9.08 & 35.26 & $0.01 *$ \\
\hline & $\begin{array}{l}\text { Within } \\
\text { Groups }\end{array}$ & 98.42 & 382 & 0.25 & & \\
\hline & Total & 107.50 & 383 & & & \\
\hline \multirow{3}{*}{$\mathrm{pH}$} & $\begin{array}{c}\text { Between } \\
\text { Groups }\end{array}$ & 1.22 & 1 & 1.22 & 2.43 & 0.12 \\
\hline & $\begin{array}{l}\text { Within } \\
\text { Groups }\end{array}$ & 192.43 & 382 & 0.50 & & \\
\hline & Total & 193.66 & 383 & & & \\
\hline \multirow{3}{*}{$\begin{array}{c}\text { Organic } \\
\text { Matter }\end{array}$} & $\begin{array}{c}\text { Between } \\
\text { Groups }\end{array}$ & 1.18 & 1 & 1.18 & 1.01 & 0.31 \\
\hline & $\begin{array}{l}\text { Within } \\
\text { Groups }\end{array}$ & 450.18 & 382 & 1.17 & & \\
\hline & Total & 451.36 & 383 & & & \\
\hline \multirow{3}{*}{ Total } & $\begin{array}{l}\text { Between } \\
\text { Groups }\end{array}$ & 0.02 & 1 & 0.02 & 9.13 & $0.01^{*}$ \\
\hline & $\begin{array}{l}\text { Within } \\
\text { Groups }\end{array}$ & 0.84 & 382 & 0.01 & & \\
\hline & Total & 0.86 & 383 & & & \\
\hline
\end{tabular}

$(* P<0.01)$ 
168 | E. Yalçın et al. / Hacettepe J. Biol. \& Chem., 2016, 44 (2), 161-171

Table 3. Seasonal comparison of soil parameters by using one-way variance analysis (ANOVA) between grazing and ungrazing parts.

\begin{tabular}{|c|c|c|c|c|c|c|c|}
\hline Season & $\begin{array}{c}\text { Soil } \\
\text { Parameters }\end{array}$ & & $\begin{array}{l}\text { Sum of } \\
\text { Squares }\end{array}$ & $d f$ & $\begin{array}{l}\text { Mean } \\
\text { Square }\end{array}$ & $\mathrm{F}$ & Sig. \\
\hline \multirow{6}{*}{ Winter } & \multirow{3}{*}{$\mathrm{CaCO}_{3}$} & $\begin{array}{l}\text { Between } \\
\text { Groups }\end{array}$ & 2.86 & 1 & 2.86 & 15.52 & $0.01 *$ \\
\hline & & $\begin{array}{l}\text { Within } \\
\text { Groups }\end{array}$ & 17.33 & 94 & 0.18 & & \\
\hline & & Total & 20.20 & 95 & & & \\
\hline & \multirow{3}{*}{ Total Salinity } & $\begin{array}{c}\text { Between } \\
\text { Groups }\end{array}$ & 0.04 & 1 & 0.04 & 6.69 & $0.01 *$ \\
\hline & & $\begin{array}{l}\text { Within } \\
\text { Groups }\end{array}$ & 0.68 & 94 & 0.01 & & \\
\hline & & Total & 0.73 & 95 & & & \\
\hline \multirow{6}{*}{ Spring } & \multirow{3}{*}{$\mathrm{N}$} & $\begin{array}{c}\text { Between } \\
\text { Groups }\end{array}$ & 0.06 & 1 & 0.06 & 4.29 & $0.04 * *$ \\
\hline & & $\begin{array}{l}\text { Within } \\
\text { Groups }\end{array}$ & 1.49 & 94 & 0.01 & & \\
\hline & & Total & 1.56 & 95 & & & \\
\hline & \multirow{3}{*}{$\mathrm{CaCO}_{3}$} & $\begin{array}{c}\text { Between } \\
\text { Groups }\end{array}$ & 4.31 & 1 & 4.31 & 10.46 & $0.01 *$ \\
\hline & & $\begin{array}{l}\text { Within } \\
\text { Groups }\end{array}$ & 38.71 & 94 & 0.41 & & \\
\hline & & Total & 43.02 & 95 & & & \\
\hline \multirow{6}{*}{ Summer } & \multirow{3}{*}{$\mathrm{CaCO}_{3}$} & $\begin{array}{c}\text { Between } \\
\text { Groups }\end{array}$ & 0.97 & 1 & 0.97 & 6.14 & $0.01 *$ \\
\hline & & $\begin{array}{l}\text { Within } \\
\text { Groups }\end{array}$ & 14.84 & 94 & 0.15 & & \\
\hline & & Total & 15.81 & 95 & & & \\
\hline & \multirow{3}{*}{ Total Salinity } & $\begin{array}{c}\text { Between } \\
\text { Groups }\end{array}$ & 0.01 & 1 & 0.01 & 6.06 & $0.01^{*}$ \\
\hline & & $\begin{array}{l}\text { Within } \\
\text { Groups }\end{array}$ & 0.03 & 94 & 0.01 & & \\
\hline & & Total & 0.03 & 95 & & & \\
\hline \multirow{6}{*}{ Fall } & \multirow{3}{*}{$P$} & $\begin{array}{c}\text { Between } \\
\text { Groups }\end{array}$ & 0.01 & 1 & 0.01 & 5.09 & $0.02 * *$ \\
\hline & & $\begin{array}{l}\text { Within } \\
\text { Groups }\end{array}$ & 0.01 & 94 & 0.01 & & \\
\hline & & Total & 0.01 & 95 & & & \\
\hline & \multirow{3}{*}{$\mathrm{CaCO}_{3}$} & $\begin{array}{c}\text { Between } \\
\text { Groups }\end{array}$ & 1.62 & 1 & 1.62 & 5.83 & $0.01^{*}$ \\
\hline & & $\begin{array}{l}\text { Within } \\
\text { Groups }\end{array}$ & 26.24 & 94 & 0.27 & & \\
\hline & & Total & 27.86 & 95 & & & \\
\hline
\end{tabular}


Table 4. Pearson correlation coefficients between soil parameters of grazing and ungrazing parts.

\begin{tabular}{|c|c|c|c|c|c|c|c|c|}
\hline Practice & $\begin{array}{c}\text { Soil } \\
\text { Parameters }\end{array}$ & $\mathrm{N}$ & $P$ & K & $\mathrm{CaCO}_{3}$ & $\mathrm{pH}$ & $\begin{array}{l}\text { Organic } \\
\text { Matter }\end{array}$ & $\begin{array}{l}\text { Total } \\
\text { Salinity }\end{array}$ \\
\hline \multirow{7}{*}{ Grazing } & $\mathrm{N}$ & - & -0.06 & $-0.18 *$ & $0.52 * *$ & $0.30 * *$ & 0.12 & -0.01 \\
\hline & $P$ & -0.06 & - & 0.14 & -0.05 & 0.09 & $-0.17 *$ & -0.05 \\
\hline & K & $-0.18 *$ & 0.14 & - & 0.05 & $0.45^{* *}$ & $-0.37 * *$ & 0.05 \\
\hline & $\mathrm{CaCO}_{3}$ & $0.52 * *$ & -0.05 & 0.05 & - & $0.72 * *$ & $-0.17 *$ & -0.08 \\
\hline & $\mathrm{pH}$ & $0.30 * *$ & 0.09 & $0.45^{* *}$ & $0.72 * *$ & - & $-0.50 * *$ & $-0.14^{*}$ \\
\hline & $\begin{array}{l}\text { Organic } \\
\text { Matter }\end{array}$ & 0.12 & $-0.17 *$ & $-0.37 * *$ & $-0.17 *$ & $-0.50 * *$ & - & 0.01 \\
\hline & Total Salinity & -0.01 & -0.05 & 0.05 & -0.08 & $-0.14 *$ & 0.01 & - \\
\hline \multirow{7}{*}{ Ungrazing } & $\mathrm{N}$ & - & -0.04 & $-0.38 * *$ & $-0.19 * *$ & 0.06 & $0.34 * *$ & $-0.36 * *$ \\
\hline & $\mathrm{P}$ & -0.04 & - & $0.52 * *$ & -0.11 & 0.08 & $-0.16^{*}$ & 0.08 \\
\hline & K & $-0.38 * *$ & $0.52 * *$ & - & $0.46^{* *}$ & $0.54 * *$ & $-0.54 * *$ & $0.59 * *$ \\
\hline & $\mathrm{CaCO}_{3}$ & $-0.19 * *$ & -0.11 & $0.46^{* *}$ & - & $0.79 * *$ & $-0.42 * *$ & $0.65^{* *}$ \\
\hline & $\mathrm{pH}$ & 0.06 & 0.08 & $0.54^{* *}$ & $0.79 * *$ & - & $-0.47 * *$ & $0.54 * *$ \\
\hline & $\begin{array}{l}\text { Organic } \\
\text { Matter }\end{array}$ & $0.34 * *$ & $-0.16 *$ & $-0.54 * *$ & $-0.42 * *$ & $-0.47 * *$ & - & $-0.24 * *$ \\
\hline & Total Salinity & $-0.36 * *$ & 0.08 & $0.59 * *$ & $0.65^{* *}$ & $0.54^{* *}$ & $-0.24 * *$ & - \\
\hline
\end{tabular}

$* P<0.05 . * * P<0.01$

The number of negative correlations were more than positive correlations that exhibited by the soil parameters between grazing and ungrazing lands (Table 4). In grazed parts, soil nitrogen showed positively correlation with soil $\mathrm{pH}$ and $\mathrm{CaCO}_{3}$, while there was a negative correlation among of soil nitrogen, total salinity and $\mathrm{CaCO}_{3}$, in ungrazed parts. Similarly, there was only positive correlation between soil $\mathrm{P}$ and $\mathrm{K}$ in protected parts. There was a negative correlation in grazed parts while positive correlation in ungrazed parts between soil $\mathrm{pH}$ and total salinity. A positive correlation was observed between the soil organic matter and nitrogen in ungrazed parts (Table 4).

\section{DISCUSSION}

Grazing affects the amount of soil nutrients in meadow ecosystems. This effect may be in different ways such as trampling, biomass consumption and accumulation of feces. Sometimes, the literature has been contradictory about grazing effects on the soil organic matter and nutrient status [12]. The reasons are different environmental conditions and grazing regime. Therefore, it is very difficult, to make a precise definition between the effects of grazing and the availability of soil organic matter and nutrients. Still, it has been accepted in a meadow ecosystems that the increases of available nitrogen and phosphorus consist via to defecation of grazing animals while the losses occur due to erosion, washing or nutrient circulation between soil and plants [12-14]. Annualy, our data also support these conclusions while seasonaly contradict.

It has been reported that grazing increase the soil nitrogen ratio in many studies $[12,15,16]$. However, the amount of nitrogen in the soil is related to the age of the land. The youngest landscape has lower while the oldest has high soil nitrogen [17]. The amount of soil organic matter and nitrogen exhibit positive correlation that confirms to decompose organic matter. Naeth and Chanasyk (1995) [18] reported that both grazing and seasonal changes affect the amount 
of organic matter in the meadow ecosystem soils. The organic matter in the meadow ecosystem soils is used both phosphorus and nitrogen mineralization as an important source [15]. The season of began to decline in plant growth rate will exceed the rate of mineralization of nitrogen that increases amount of nutrient uptake in the meadow soils [19]. Our data supported that both the amount of organic substances and consequently vary the quantity of nitrogen and phosphorus at ungrazed stands in some seasons.

In grazing parts of the study area, phosphorus content was high as similar to nitrogen. The high phosphorus content often seen depending on grazing in the meadow soils. Because, an adult cattle meanly produces $25 \mathrm{~kg}$ of feces and urine $9 \mathrm{~kg}$ per day, and fresh cattle feces and urine averagely consist of $0.18 \%$ and $0.01 \% \mathrm{P}_{2} \mathrm{O}_{5}$ respectively [20]. Moreover, soil phosphorus is one of the main components of the organic material and is provided almost entirely from the bedrock. Increasing grazing pressure is also effective on soil phosphorus content in this study [16].

$\mathrm{pH}$ decreases from west to east in the study area. The reason is that the soils are washed with increasing precipitation. $\mathrm{pH}$ acts as a indicator for two basic nutrients in the soil. These elements are $\mathrm{Ca}$ and $\mathrm{Mg}$. Calcium ensures the nutrients absorption and cations selection from soil and it is one of the important indicators of soil fertility [21]. Ca content decreases in asidic soil, so, $\mathrm{CaCO}_{3}$ ratio decreased in the east of study area. Grazing animals affect meadow ecosystem soils via to trampling compacts and increases bulk density [22]. In such soils, $\mathrm{CaCO}_{3}$ doesn't move away by washing and its concentration increases [23]. This process supports our results.

There are a number of study to evaluate the soil salinity in terms of the seasonality, grazing, and vegetation relationships in the meadow ecosystem [24]. Usually the soil salinity in the ungrazed plots is higher than in grazed. Grazing reduces the plant coverage and litter, so it is observed to increase in evaporation from soil via to raising soil temperature in the meadow ecosystems $[25,26]$. Especially in spring and summer, we observed that the total salinity of upper soil layer increased in grazing stands.

\section{CONCLUSION}

In this study, grazing has led to a statistically significant annual and seasonal changes in which we measure some of the soil parameters. It is important that controlled grazing should be done to sustainable use the primary production and conservation of biodiversity in meadow ecosystems used as rangeland.

\section{References}

1. J.F. Dormaar, A. Johnston, S. Smoliak, Seasonal variation in chemical characteristics of grazed and ungrazed mixed prairie and fescue grassland, J. Range Manage., 30 (1977) 195.

2. M.A. Rodriguez, Y.K. Brown, S.A. Gomez, The vertical distribution of belowground biomass in grassland communities in relation to grazing regime and habitat characteristics, J. Veg. Sci., 6 (1995) 63.

3. J.A. Griffith, K.P. Price, E.A. Martinko, A multivariete analysis of biophysical parameters of tallgrass prairie among land management practices and years, Environ. Monit. Assess., 68 (2001) 249.

4. A. Johnston, J.F. Dormaar, S. Smoliak, Long-term grazing effects on fescue grassland soils, J. Range Manage., 24 (1971) 185.

5. S. Smoliak, J.F. Dormaar, A. Johnston, Long-term grazing effects on Stipa-Bouteloua prairie soils, J. Range Manage., 25 (1972) 246.

6. T. Yakupoğlu, F. Sarıoğlu, O. Dengiz, Morphology, physico-chemical characteristics and classification of two vertisols in Bafra and Çarşamba delta plains, Ondokuz Mayıs University, Anadolu Journal of Agricultural Science 25 (2012) 67.

7. E. Yalçın, M. Kılınç, H.G. Kutbay, A. Bilgin, H. Korkmaz, The Lowland Meadow Vegetation of the Central Black Sea Region of Turkey, Ekoloji 23 (2014) 36.

8. M. Trémolières, A. Schnitzler, J.M. Sánchez-Pérez, D. Schmitt, Changes in foliar nutrient content and resorption Fraxinus excelsior L., Ulmus minor Mill. and Clematis vitalba L. after prevention floods. Ann. For. Sci., 56 (1999) 641.

9. S.E. Allen, N.M. Grimshaw, J.A. Parkinson, C. Quarmby, J.D. Roberts, Methods in Plant Ecology, Blackwell Scientific Publications, Oxford, 1986.

10. B. Kacar, Soil Analysis, Nobel Publications, Ankara, 2009.

11. Anonymous, SPSS for Windows. Version 21.0.0 SPSS Inc. Chicago, IL, USA, 2012.

12. R.S. Lavado, J.O. Sierra, P.N. Hashimoto, Impact of grazing on soil nutrients in Pampean grassland, J. Range Manage., 49 (1996) 452. 
13. F. Raiesi, E. Asadi, Soil microbial activity and litter turnover in native grazed and ungrazed rangelands in a semiarid ecosystem, Biol. Fertil. Soils 43 (2006) 76

14. H. Yan, M. Cao, J. Liu, B. Tao, Potential and sustainability for carbon sequestration with improved soil management in agricultural soils of China, Agr. Ecosyst. Environ., 121 (2007) 325.

15. J.F. Dormaar, S. Smoliak, W.D. Willms, Distributions of nitrogen fractions in grazed and ungrazed fescue grassland Ah horizon, J. Range Manage., 43 (1989) 6.

16. J.F. Dormaar, W.D. Willms, Effect of forty-four years of grazing on fescue grassland soils, J. Range Manage. 51 (1998) 122.

17. R.S. Inouye, N.J. Huntly, D. Tilman, J.R. Tester, M. Stilwell, K.C. Zinnel, Old field succession on a Minnesota sand plain, Ecology, 68 (1997) 12.

18. M. Naeth, D. Chanasyk, Grazing effects on soil water in alberta foothills fescue grasslands, J. Range Manage., 48 (1995) 528.

19. S.R. Troelstra, L.A.P. Lotz, R. Wagenaar, L. Sluimer, Temporal and spatial variability in soil nutrient status of former beach plain, Plant and Soil, 127 (1990) 1.

20. J.J. Neeteson, Nitrogen and phosphorus management on Dutch dairy farms: legislation and strategies employed to meet the regulations. Biology and Fertility of Soils, 30 (2000) 566.
21. D.E. Goldberg, The distribution of evergreen and deciduous trees relative to soil type: an example from the Sierra Madre, Mexico, and a general model, Ecology, 63 (1982) 942.

22. S.W. Trimble, A.C. Mendel, The cow as geomorphic agent - a critical review. Geomorphology 13 (1995) 233.

23. I. Stavi, E.D. Ungar, H. Lavee, P. Sarah, Grazinginduced spatial variability of soil bulk density and content of moisture, organic carbon and calcium carbonate in a semi-arid rangeland. Catena, 75 (2008) 288.

24. E.J. Chaneton, R.S. Lavado, Soil nutrients and salinity after long- term grazing exclusion in a flooding pampa grassland, J. Range Manage., 49 (1996) 182.

25. R.S. Lavado, M.A. Taboada, Soil salinization as an effect of grazing in a native grassland soil in the Flooding Pampa of Argentina. Soil Use Manage., 3 (1987) 143.

26. M. Alconada, O.E. Ansin, R.S. Lavado, V.A. Deregibus, G. Rubio, F.H. Gutierrez, Effect of retention of runoff water and grazing on soil and on vegetation of a temperate humid grassland. Agri. Water Manage., 23 (1993) 233. 
